\title{
Top-down control of methane emission and nitrogen cycling by waterfowl
}

\author{
R. SCOTt Winton ${ }^{1}$ And Curtis J. Richardson
}

Duke University Wetland Center, Nicholas School of the Environment, Duke University, Durham, North Carolina 27708 USA

\begin{abstract}
Aquatic herbivores impose top-down control on the structure of wetland ecosystems, but the biogeochemical consequences of herbivory on methane $\left(\mathrm{CH}_{4}\right)$ and nitrogen $(\mathrm{N})$ are poorly known. To investigate the top-down effects of waterfowl on wetland biogeochemistry, we implemented exclosure experiments in a major waterfowl overwintering wetland in the southeastern United States over two growing seasons. We found that herbivory inhibited the oxidation of $\mathrm{CH}_{4}$, leading to a mean increase in emission by $230 \%$ over control plots, and prevented nitrification, as indicated by low nitrate availability and undetectable emissions of nitrous oxide. Herbivory reduced belowground biomass of macrophytes, retarding the subsequent spring emergence of aerenchymous stems, effectively starving wetland soils of oxygen necessary for $\mathrm{CH}_{4}$ oxidation and nitrification. The recognition that important populations of aquatic herbivores may influence the capacity for wetlands to emit greenhouse gases and cycle $\mathrm{N}$ is particularly salient in the context of climate change and nutrient pollution mitigation goals. For example, our results suggest that (1) annual emissions of $23 \mathrm{Gg} \mathrm{CH}_{4} / \mathrm{yr}$ from $\sim 57000$ ha of publicly owned waterfowl impoundments in the southeastern United States could be tripled by overgrazing and that (2) waterfowl impoundments may export as much $\mathrm{N}$ as agricultural fields. We discuss potential implications for habitat management in the context of historic wetland loss and waterfowl population recovery.
\end{abstract}

Key words: greenhouse gas; herbivory; methane emissions; nitrification; nitrogen cycling; top-down control; waterfowl; wetlands.

\section{INTRODUCTION}

Ecosystem structure is strongly influenced by herbivory in many contexts (Milchunas et al. 1988, Hulme 1996, Augustine and McNaughton 1998, Olff and Ritchie 1998, Malhi et al. 2016) and wetlands are no exception. Recent high-profile work in salt marshes demonstrated the impact of grazing snails on the extent of salt marshes (Silliman et al. 2005), and the ability of herbivores, such as waterfowl (anseriformes, i.e., ducks, geese, and swans), to alter the density and composition of wetland vegetation has been recognized for decades (Anderson and Low 1976, Evers et al. 1998, Idestam-Almquist 1998, Froelich and Lodge 2000, Badzinski et al. 2006, Veen et al. 2013). Yet, the biogeochemical consequences of such intensive herbivory are largely unknown, especially as it relates to greenhouse gas fluxes and nitrogen $(\mathrm{N})$ cycling.

Methane $\left(\mathrm{CH}_{4}\right)$ emission and $\mathrm{N}$ removal by wetlands are biogeochemical processes of critical environmental importance. Wetlands are the greatest source of atmospheric $\mathrm{CH}_{4}$, a potent greenhouse gas (Bridgham et al. 2006), and they are also valued for their capacity to transform, sequester, and remove excess nitrate through coupled aerobic/anaerobic nitrification/denitrification

Manuscript received 14 April 2016; revised 8 September 2016; accepted 19 September 2016. Corresponding Editor: Joseph B. Yavitt.

${ }^{1}$ E-mail: scott.winton@gmail.com
(Firestone 1982). Aquatic herbivory may serve an important, unrecognized role in climate regulation and the eutrophication of aquatic ecosystems by interacting with wetland biogeochemical functioning.

An understanding of the influence of waterfowl on wetland biogeochemistry also has important implications for organizations that manage and conserve wildlife. For example, a primary function of the U.S. Fish and Wildlife Service is to manage wetland habitats to support populations of approximately 78 million North America waterfowl (North American Waterfowl Management Plan Committee 2012). These populations have rebounded dramatically from historic lows of the 1930s (Baldassarre et al. 2006), while simultaneously, vast areas of supporting wetland habitat have been lost (Dahl 2011). An understanding of the interactions between the dense bird populations residing on federal land and the magnitude of $\mathrm{CH}_{4}$ emission from publicly managed wetland habitats is needed in order to meet the Department of the Interior mandate to achieve carbon neutrality (Fish and Wildlife Service 2010).

Hydrophytes, the food source for aquatic herbivores, are notable for their ability to efficiently transport oxygen $\left(\mathrm{O}_{2}\right)$ through aerynchyma to their roots, as well as rooting zone soils. In this process of "radial oxygen loss," $\mathrm{O}_{2}$ diffuses into soils from root tips (Armstrong 1964). The presence of an oxidized rhizosphere, essentially an extension of the oxic atmosphere into otherwise hypoxic or anoxic wetland soils, creates a complex, high 
surface-area hyporrheic zone, which facilitates the adjacency of diverse redox conditions. Thus radial $\mathrm{O}_{2}$ loss has profound influence on many wetland biogeochemical processes governed by oxidation-reduction reactions, for example, those involving iron (Green and Etherington 1977, Sundby et al. 1998), $\mathrm{CH}_{4}$ (King 1994, Jespersen et al. 1998), and N (Reddy et al. 1989).

Evidence for the importance of plant-mediated $\mathrm{O}_{2}$ transport on wetland biogeochemical functioning has inspired a few studies of herbivory effects on $\mathrm{CH}_{4}$ dynamics. Such investigations have focused on either the effects of sediment bioturbation on the potential for $\mathrm{CH}_{4}$ oxidation to occur (Huang et al. 2005, Bodelier et al. 2006), or on physical leaf damage reducing gas flow resistance and increasing the stem efflux of $\mathrm{CH}_{4}$ (Dingemans et al. 2011, Petruzzella et al. 2015). However, none of these studies address the potential biogeochemical consequences of aquatic herbivory preventing the formation of an oxidized rhizophere and none consider the potential implications for other sensitive biogeochemical processes, such as $\mathrm{N}$ cycling.

The testing of herbivory effects is made difficult because it has to be layered atop the complicated role of plants (Fig. 1). Vegetation is integral to wetland biogeochemical processes because it provides the $\mathrm{C}$ substrate, in the form of detritus and exudates, that drive all forms of wetland soil heterotrophic respiration (Whiting and Chanton 1993, Ding et al. 2005, Laanbroek 2010). In addition, the plant-mediated gas transport process flows both ways. Plants not only transport $\mathrm{O}_{2}$ into wetland soils, but they also allow gaseous byproducts of anaerobic respiration to diffuse into capillary-like root networks and follow concentration gradients up to and out of gaspermeable aerenchymous stems (Dacey and Klug 1979, Boon et al. 1995, Van der Nat and Middelburg 1998).

Experiments designed to quantify the effect of emergent plants on $\mathrm{CH}_{4}$ flux have typically utilized clipping manipulations (Schimel 1995, Shannon et al. 1996, Kelker and
Chanton 1997), which affirm that the plant-efflux pathway is important for $\mathrm{CH}_{4}$ dynamics, leading to the current paradigm that aerenchymous emergent wetland vegetation enhances $\mathrm{CH}_{4}$ emission. A literature review (Turetsky et al. 2014) confirms that, indeed, $\mathrm{CH}_{4}$ emissions tend to be greater from wetlands dominated by emergent graminoid vegetation. While this pattern is compelling, it does not disentangle the multiple ways in which plants impact $\mathrm{CH}_{4}$ emissions: via providing substrate, an efflux pathway, and an oxidized rhizosphere. Furthermore, plant community structure is partially determined by abiotic conditions, such as hydrology, soil properties, and climate, further muddying the underlying reasons for the observed correlation between $\mathrm{CH}_{4}$ and plant community.

Even the clipping experiments that form the empirical foundation of the plant- $\mathrm{CH}_{4}$ paradigm don't adequately test the holistic role that plants play. Clipping of culms below water level and/or the sealing of exposed clipped culms shuts off the gas transport, which has an instantaneous effect on the amount of $\mathrm{CH}_{4}$ leaving the plants and the amount of $\mathrm{O}_{2}$ entering sediments: both essentially drop to zero. In contrast, the poising effects of an oxidized rhizosphere, such as elevated redox potential and the presence of oxidized iron, has long-lasting effects on the production and oxidation of $\mathrm{CH}_{4}$. Because of poise and the gradual nature of alternative electron acceptor depletion, soil slurry lab incubations, for example, typically monitor $\mathrm{CH}_{4}$ production over periods of weeks or months (Bodelier et al. 2000). Thus field clipping experiments only measure short-term $\mathrm{CH}_{4}$ effects and cannot account for the temporally lagging role radial $\mathrm{O}_{2}$ loss plays in $\mathrm{CH}_{4}$ oxidation. No study has experimentally prevented vegetation from emerging (i.e., via removal of roots and tubers in winter), which would test how the lack of oxidized rhizosphere development might influence $\mathrm{CH}_{4}$ emission and contribute to a more complete understanding of the role that emergent plants and their consumers play in wetland $\mathrm{CH}_{4}$ emission.

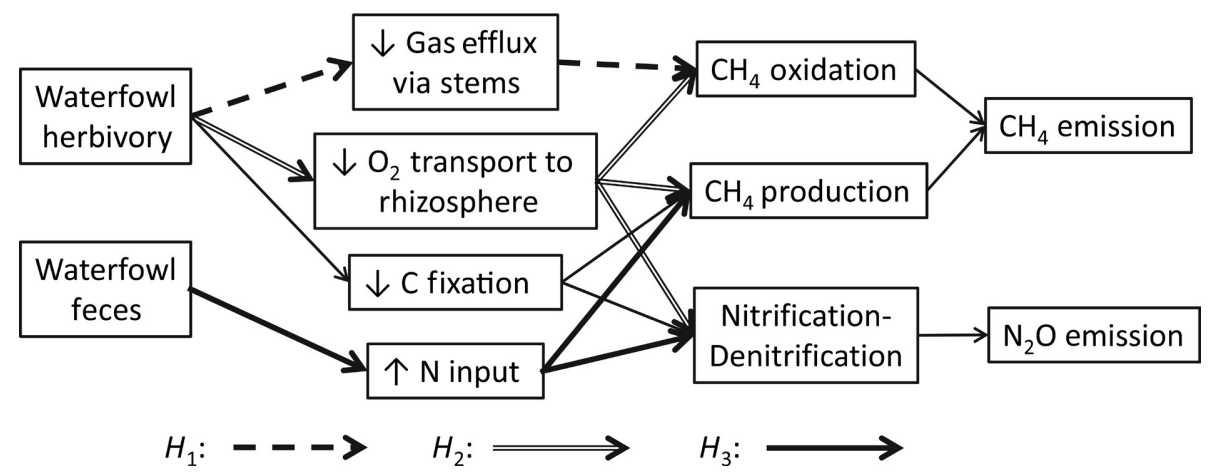

FIG. 1. Conceptual diagram of hypothetical effects of waterfowl on cycling of $\mathrm{CH}_{4}$ and $\mathrm{N}$ in wetlands. $H_{1}$ : Dashed arrows trace potential impact of herbivory disrupting plant-mediated efflux of biogenic gases, which would force $\mathrm{CH}_{4}$ to diffuse or ebulliate slowly through surficial sediments where $\mathrm{CH}_{4}$ oxidation is most effective. $\mathrm{H}_{2}$ : Split arrows trace potential impact of herbivory starving wetland sediments of plant-transported $\mathrm{O}_{2}$, which would enhance the anaerobic process of $\mathrm{CH}_{4}$ production, while inhibiting aerobic processes of $\mathrm{CH}_{4}$ oxidation and nitrification. $\mathrm{H}_{3}$ : Solid heavy arrows trace potential impact of enhanced $\mathrm{N}$ inputs from waterfowl feces, which could stimulate $\mathrm{N}$ cycling and inhibit $\mathrm{CH}_{4}$ production by increasing availability of nitrate, an efficient alternate electron acceptor. 
In addition to herbivory effects, waterfowl may influence the biogeochemical functioning of wetlands by enhancing decomposition through digestion and excretion (Malhi et al. 2016), and/or by transporting nutrients across landscapes (Doughty et al. 2015). For example, a large flock of geese in New Mexico supplies nearly $40 \%$ of $\mathrm{N}$ inputs to a managed wetland where it roosts (Post et al. 1998). It would be reasonable to assume that such a bird-derived enhancement in wetland $\mathrm{N}$ inputs would accelerate the $\mathrm{N}$ removal process of coupled nitrification-denitrification, and if so, the bird-driven increase in the availability of nitrate, an efficient alternate electron acceptor, would suppress $\mathrm{CH}_{4}$ production. These potential biogeochemical impacts of waterfowl fecal inputs have not been investigated.

In this study, we conceptually model the hypothetical impacts of waterfowl on $\mathrm{CH}_{4}$ and $\mathrm{N}$ cycling (Fig. 1) and test three specific hypotheses through a combination of field, greenhouse, and laboratory experiments. Hypothesis 1: herbivory will reduce the efflux of $\mathrm{CH}_{4}$ through plant stems suppressing $\mathrm{CH}_{4}$ emission. Hypothesis $2 \mathrm{a}$ : herbivory will diminish $\mathrm{O}_{2}$ transport into wetland sediments, thus enhancing $\mathrm{CH}_{4}$ production and limiting $\mathrm{CH}_{4}$ oxidation leading to greater $\mathrm{CH}_{4}$ emission. Hypothesis $2 \mathrm{~b}$ : diminished $\mathrm{O}_{2}$ transport into wetland sediments by plants will limit nitrification, leading to lower nitrate availability, denitrification and nitrous oxide $\left(\mathrm{N}_{2} \mathrm{O}\right)$ emission. Hypothesis 3: waterfowl feces will increase nitrate availability as an alternate electron acceptor, which will inhibit $\mathrm{CH}_{4}$ production and reduce $\mathrm{CH}_{4}$ emission.

We investigate herbivory effects in a managed freshwater waterfowl impoundment, which is a common habitat archetype in North America. Waterfowl impoundments are widespread and management practices prescribed by state governments or the U.S. Fish and Wildlife Service drive these ecosystems toward convergent hydrologic and vegetation-herbivore regimes (Strader et al. 2005). Therefore we hypothesize that waterfowl populations have the potential to collectively exert important effects on $\mathrm{CH}_{4}$ and $\mathrm{N}$ cycling across a large portfolio of publicly-managed emergent freshwater waterfowl impoundments in the southeastern United States. We summarize the extent of these waterfowl habitats and estimate their annual $\mathrm{CH}_{4}$ emission to provide a contextualized regional estimate of their aggregate contribution to greenhouse gas flux.

\section{Methods}

\section{Field site description}

We implemented our exclosure experiment at Marsh Impoundment 10 North (MI10N) $\left(35^{\circ} 32^{\prime} 08 \mathrm{~N}\right.$, $76^{\circ} 04^{\prime} 24 \mathrm{~W}$ ), an 88 -ha wetland constructed specifically to provide habitat for migratory birds at Mattamuskeet National Wildlife Refuge (MNWR) in Hyde County, North Carolina, United States. Dominant plant species in MI10N include Phragmites australis, Eleocharis quadrangulata, Panicum dichotomiflorum, Bacopa monieri, and Alternanthera philoxeroides. MI10N soil is mapped as Weeksville loam (95\%) and Engelhard loamy very fine sand (5\%; Soil Survey Staff 2015). At the east end of the refuge, MI10N is closed to hunting and has restricted public access. The climate is humid subtropical (Köppen climate classification $C f a$ ) with July daytime temperatures regularly reaching $32^{\circ} \mathrm{C}$ and temperatures regularly dropping below $0^{\circ} \mathrm{C}$ during boreal winter (Peel et al. 2007). The area receives a mean of approximately $130 \mathrm{~cm}$ of precipitation annually (National Climatic Data Center).

A network of canals, flow control structures, and pumps allow MNWR staff to control water levels in MI10N and other impoundments, which they do, following an Annual Marsh/Water Management Plan prepared by the U.S. Fish and Wildlife North Carolina Migratory Bird Field Office to meet habitat objectives for migratory waterfowl and shorebirds (John Stanton, personal communication). Generally, the purpose of drawdowns is to promote the establishment of desired plant species. In June 2013, pumps were run for approximately $8 \mathrm{~d}$ to draw down $16 \mathrm{~cm}$ of standing water to soil surface. In May 2014, pumps were run for approximately $17 \mathrm{~d}$ to draw down $34 \mathrm{~cm}$ of standing water to soil surface.

Aerial surveys on the Refuge and surrounding agricultural fields have recorded recent 5-yr means of 180000 ducks and 32000 Tundra Swan (Cygnus Columbianus; Wires 2015; Fig. 2A, B). Increases in local waterfowl numbers reflect long-running positive trends in North American populations attributed to decades of successful management efforts (e.g., habitat preservation, restoration and construction; hunting regulations). Peak waterfowl counts recorded by Refuge staff during bimonthly surveys at MI10N included 5036 C. columbianus and 4992 dabbling ducks (Wires 2015), corresponding to a density of roughly 110 herbivores/ha.

\section{Exclosure experiment}

To test for waterfowl effects, we established eight $2 \times 2 \mathrm{~m}$ plastic bird exclosures in October 2012 (Fig. 2C). Exclosures were removed during waterfowl absence from March to October, 2013 to allow other large-bodied fauna, such as turtles, wading birds, raccoon (Procyon lotor), nutria (Myocastor coypus), muskrat (Ondatra zibethicus), white-tailed deer (Odocoileus virginianus), and red wolf (Canis rufus), to have unimpeded access to plots. We initially established four bird-accessible plots and added an additional four in spring of 2013 for a balanced experiment of eight exclosure and eight "bird" plots. We chose eight replicates in order to detect trends despite the high spatial variability of $\mathrm{CH}_{4}$ emission within wetlands (Whalen 2005, Strack and Waddington 2008). We sited plots randomly within a zone dominated by the emergent Eleocharis quadrangulata, a species known to support an oxidized rhizosphere (Michaud and Richardson 1989) and to serve as a food item for waterfowl (Rodewald 2015). Within each plot, we installed a permanent 


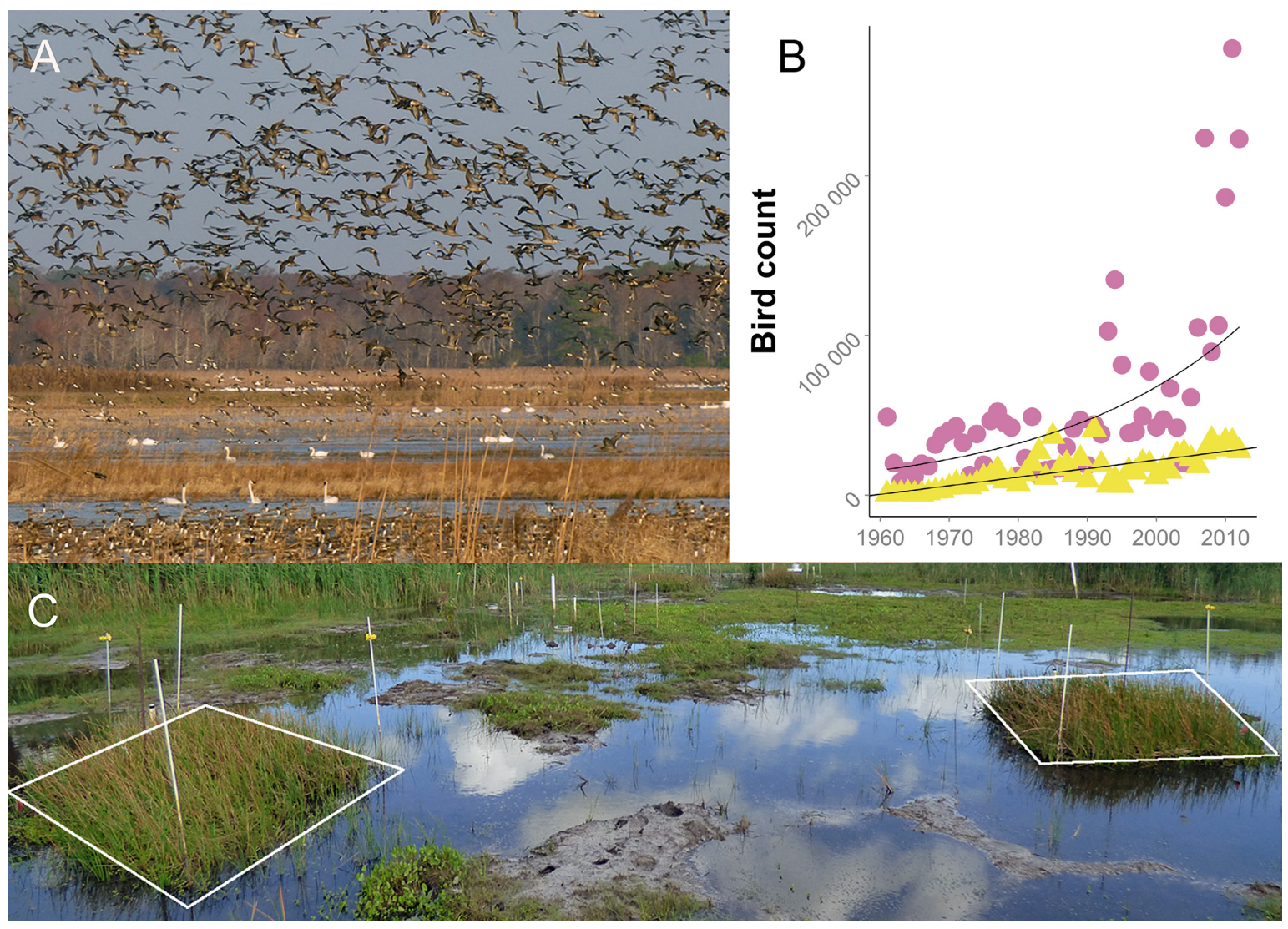

FIG. 2. Massive flocks of waterfowl impact aquatic vegetation at Mattamuskeet National Wildlife Refuge in North Carolina, USA. (A) Mixed species waterfowl mega-flock. (B) Total ducks (pink circles) and swans (yellow triangles) counted at the Refuge during Midwinter Waterfowl Inventories by U.S. Fish and Wildlife Service 1961 to 2012. (C) Dense stands of spike rush (E. quadrangulata) in May within white quadrangles which delineate extent of exclosures (only installed from November through March) to prevent grazing by waterfowl.

porewater well for interstitial water sampling at approximately $15 \mathrm{~cm}$ depth and an enamel-coated $2 \mathrm{~m}$ rebar rod to serve as a base for static chamber gas sampling.

\section{Static chamber trace gas sampling}

The nature of the study required that we design and build static chambers with the following criteria in mind: (1) chambers should be tall so that emergent vegetation can be left intact during sampling as clipping can impact plant-mediated flux (Laanbroek 2010); (2) chambers should be transparent so that plants can be photosynthetically active during incubations as gas may be emitted via stomata (Laanbroek 2010); and (3) chamber setup and sampling should be possible without disturbing wetland sediments as this can cause ebullition that biases flux data (Winton and Richardson 2015). We built static chambers from $1-\mathrm{m}$ sections of $55 \mathrm{~cm}$ diameter TEDLAR plastic sleeves that pass $88 \%$ of photosynthetically active radiation with circular plexiglas caps fringed with closed-cell foam to make an air-tight seal. We affixed the cap with a 2-m sampling tube (1 mm inner diameter), a wide-bore closeable exhaust vent and a thermocouple for measuring internal chamber temperature $(T)$. To set up the static chamber apparatus for trace gas sampling we attached the cap to the sleeve using binder clips, inserted a plastic brace into the base of the sleeve to maintain a cylindrical chamber headspace, and carried it into the wetland hanging from a $2-\mathrm{m}$ PVC pole. With the exhaust vent open, we lowered the chamber to rest on the rebar base using the PVC pole. As the chamber "skirt" submerged, air displaced by standing water was able to escape via the exhaust vent. We closed the vent before extracting the first headspace sample. We conducted chamber set up and sampling from a submerged cinder block platform $2 \mathrm{~m}$ away from rebar base to avoid disturbing sediments and driving ebullition into the chamber. Before extracting each sample, we flushed the sampling tube with ambient air to mix this small volume (approximately $3 \mathrm{~mL}$ ) with the larger headspace (approximately $160 \mathrm{~L}$ ). We sampled $60 \mathrm{~mL}$ of headspace immediately following chamber set up and four additional samples at 5-8 min intervals for a total of five samples over an incubation of approximately $30 \mathrm{~min}$. We recorded internal chamber temperature immediately following each extracted sample. We measured chamber height above 
water level to calculate cylindrical chamber volume. During sampling dates with low or no surface water (July and September 2013, May and June 2014), use of the chamber described here was not possible because standing water is necessary to create a sealed headspace. Instead, we used a permanent collar static chamber method, with a water-filled gutter and remote rod sampling system (Winton and Richardson 2015). Because of smaller chamber volume (approximately $15 \mathrm{~L}$ ), we extracted four headspace samples instead of five. We sampled trace gas emissions monthly from after the departure of waterfowl until after impoundment drawdown in the middle of the growing season (March/April to June/July) and seasonally during fall and winter when we did not expect to find significant $\mathrm{CH}_{4}$ emissions due to low water and low temperature, respectively.

\section{Trace gas analysis}

We stored gas samples collected at the field site in labeled Mylar bags for transport back to the Duke University Wetland Center laboratory. We analyzed samples for $\mathrm{CH}_{4}$ and nitrous oxide within one week of collection using a Varian 450 gas chromatograph (Bruker, Billerica, Massachusetts, USA) equipped with a flame ionization detector and electron capture detector. We ran all samples in duplicate with the mean value used for gas flux calculations unless duplicate values differed by $>10 \%$, in which case the obviously outlying value was assumed to stem from analytical error and discarded. We determined concentration of $\mathrm{CH}_{4}$ and $\mathrm{N}_{2} \mathrm{O}$ from simultaneous measurements of five standard concentrations (Airgas Specialty Gases, Durham, North Carolina, USA) and controlled for drifting baseline by running pairs of check standards for every 10 samples. Flux was estimated by linear regression of sample concentration as a function of time elapsed. If a threshold $r^{2}$ value of 0.90 was not met, we removed one or two outlying point if it improved fit to $>0.90$ ( $15 \%$ of incubations), otherwise such estimates were treated as failed incubations and excluded from subsequent analysis (3\% of incubations). We estimate the minimum detectable flux for $\mathrm{CH}_{4}$ was $0.037 \mathrm{mg}$ $\mathrm{CH}_{4} \cdot \mathrm{m}^{-2} \cdot \mathrm{h}^{-1}$. For all flux estimates $<3$ times this minimum detectable flux, we instead imputed the minimum value for analysis ( $24 \%$ of incubations). We followed the same protocol for nitrous oxide, except that we estimated a minimum detectable flux of $0.013 \mathrm{mg} \mathrm{N} \mathrm{N}_{2} \mathrm{O} \cdot \mathrm{m}^{-2} \cdot \mathrm{h}^{-1}$.

\section{Cumulative methane flux analyses}

We estimate cumulative $\mathrm{CH}_{4}$ flux from each experimental plot for the duration of the experiment by interpolating linearly between field measurements and then calculated area under the resulting curve (Wickland et al. 1999). We excluded curves with missing data points (due to failed incubations) from subsequent analysis. We logtransformed the remaining cumulative $\mathrm{CH}_{4}$ flux data to better meet the assumption of normality and equal variance and tested the hypothesis that bird plots emitted more cumulative $\mathrm{CH}_{4}$ than exclosure plots using a Welch's $t$ test. To estimate the effect of bird herbivory and bird exclusion on cumulative flux we calculated the ratio of geometric mean cumulative $\mathrm{CH}_{4}$ flux from exclosure and bird plots. We report this ratio as the effect of herbivory (233\% increase) on $\mathrm{CH}_{4}$ flux. We used the same method to calculate the difference between 2013 and 2014 peak season cumulative $\mathrm{CH}_{4}$ fluxes and to estimate the yearly contribution of the peak season compared to the rest of the year. To estimate annual $\mathrm{CH}_{4}$ emission we calculated cumulative emissions from two 12-month periods of data that each cover one of the two early growing season $\mathrm{CH}_{4}$ emission peaks in 2013 and 2014. We used the arithmetic mean of these two annual $\mathrm{CH}_{4}$ flux estimates to report annual flux from the site with and without birds.

\section{Dissolved trace gas measurement}

To evaluate soil $\mathrm{CH}_{4}$ production and assess the role played by ebullition in $\mathrm{CH}_{4}$ emission in our plots, we calculated dissolved trace gases using the headspace equilibrium method (Kampbell et al. 1989). Briefly, we injected $50 \mathrm{~mL}$ of soil pore water into mylar gas bags preloaded with $100 \mathrm{~mL}$ of dinitrogen. We vigorously shook all bags for five minutes to ensure equilibrium between liquid and gas phases at lab $T$ and pressure and then extracted headspace gas for analysis by gas chromatograph. We used Henry's law to estimate dissolved $\mathrm{CH}_{4}$ in the water samples based on the concentration of $\mathrm{CH}_{4}$ in headspace.

\section{Extractable nitrate}

To evaluate the amount of $\mathrm{O}_{2}$ available to surface sediments, we tested surface soils for nitrate/nitrite, which is produced by the aerobic process of nitrification. During each site visit, we collected surface soil (top $5 \mathrm{~cm}$ ) from each plot in triplicate and made a field composite. We performed a potassium chloride salt extraction on a 5-g soil subsample. We analyzed the extracts for nitrate/nitrite using a Lachat Quickchem 8000 autoanalyzer (Hach, Loveland, Colorado, USA). We weighed and then oven-dried the remaining soil to calculate a wet:dry ratio, which we used to estimate extractable $\mu \mathrm{g}$ nitrate/nitrite per $\mathrm{g}$ of dry soil.

\section{Drawdown nitrogen loading}

We collected four replicate impoundment surface water samples monthly in spring of 2013 and 2014. We measured nitrate/nitrite $\left(\mathrm{NO}_{\mathrm{x}}\right)$ and ammonia/ammonium $\left(\mathrm{NH}_{\mathrm{x}}\right)$ using a Lachat Quickchem 8000 autoanalyzer and total phosphorus using the persulfate-digestion-molybdate-blue method (Wetzel and Likens 2000). We measured total N using a Shimadzu TOC-L (Shimadzu Corporation, Kyoto, Japan) in 2014 only (this instrument was not available in 2013). We found total $\mathrm{N}$ to be strongly 
correlated $\left(r^{2}=0.87\right)$ with $\mathrm{NH}_{\mathrm{x}}$ at MI10N during spring of 2014. We assume that a similar relationship between $\mathrm{NH}_{\mathrm{x}}$ and total $\mathrm{N}$ existed in 2013 and we use a simple linear model to estimate total $\mathrm{N}$ from measured $\mathrm{NH}_{\mathrm{x}}$ data in 2013. Mean residual error from the model is $<10 \%$.

We estimate the mass of Ninputs to Lake Mattamuskeet from springtime impoundment drawdown by multiplying impoundment water volume by total $\mathrm{N}$ concentration of surface water. We measured MI10N water level hourly using an Odyssey Capacitance Water Level Logger (Dataflow Systems, Christchurch, New Zealand) and multiplied water depth at start of drawdown by impoundment area to calculate water volume. We used the mean surface water concentration from the measurement date closest to the timing of drawdown for our loading calculation. These key sampling dates were 9 June 2013, three days before drawdown, and 31 May 2014, roughly eight days after drawdown.

\section{Vegetation measurements}

To detect grazer effects on vegetation, we conducted stem counts and measured belowground biomass. Each time we measured gas flux, we used the static chamber footprint as a sample area to estimate emergent stem density in each plot. We counted emergent $E$. quadrangulata stems within the chamber footprint and converted to stems per square meter. In April 2013, we took three replicate $30 \mathrm{~cm}$ deep punch cores from each plot using a $10 \mathrm{~cm}$ diameter plunger corer. We split the cores into surface to $15 \mathrm{~cm}$ and $15-30 \mathrm{~cm}$ sections and passed them through a 2-mm sieve to extract coarse belowground biomass. We oven-dried and then weighed the belowground biomass.

\section{Direct observations of herbivore activity}

To document and quantify herbivore activity in our un-exclosed plots, we deployed time-lapse cameras during the waterfowl seasons (November to March) of both study years. Cameras captured images of four plots every five minutes during daylight hours generating approximately 80000 images. We counted swans and ducks present within plots and divided by 12 to yield an estimate of bird-use hours.

\section{Mesocosm experiment}

To test for effects of bird nutrient inputs on $\mathrm{CH}_{4}$ flux we implemented a mesocosm dosing experiment in the Duke University Greenhouse. In September 2013, long after seasonal bird droppings were well-decomposed, we collected $10 \mathrm{~kg}$ of soil from our field site at Mattamuskeet National Wildlife Refuge in each of 24 5-gallon (19-L) plastic buckets. We let the buckets sit in the greenhouse for six months before commencing the experiment. We multiplied our bird-use estimates, derived from our direct camera trap observations, by published waterfowl defecation masses and rates (Hahn et al. 2007) to estimate a range of fecal mass that should be added to a mesocosm to simulate in situ loading. We collected waterfowl feces from Sylvan Heights Waterfowl Park in Scotland Neck, North Carolina and in March 2014 and dosed one-third of mesocosms with approximately $30 \mathrm{~g}$ of feces, one-third with approximately $10 \mathrm{~g}$ of feces, and left the final onethird as a negative control. To simulate field conditions, fecal matter was sprinkled into inundated mesocosms and not mixed. We report results from June and July, 73 and $103 \mathrm{~d}$ after initial dosage, respectively.

\section{Potential methane production assay}

To test whether bird activity increased the capacity for impoundment soil to produce $\mathrm{CH}_{4}$ we set up a potential $\mathrm{CH}_{4}$ production assay in vitro (Bodelier et al. 2000). We collected surface soils $(0-5 \mathrm{~cm})$ from the field experiment plots in triplicate in June 2014 and placed approximately $20 \mathrm{~g}$ in each of three 150 -mL flasks sealed with needlepermeable butyl stoppers for a total of 48 incubations. To create an anoxic setting for the soil, we added $100 \mathrm{~mL}$ of helium-sparged deionized water and three times evacuated and replaced flask headspace with dinitrogen $\left(\mathrm{N}_{2}\right)$ using a vacuum pump/ $\mathrm{N}_{2}$ tank manifold connected directly to the flasks with Teflon tubing and needles. To sample flask headspace, we forced $20 \mathrm{~mL}$ of $\mathrm{N}_{2}$ through a syringe and immediately withdrew an equal amount. To calculate the amount of $\mathrm{CH}_{4}$ present in the flask we took into account $\mathrm{N}_{2}$ dilution of headspace as well as dissolution into flask water based on Henry's Law. We measured soil headspace for $\mathrm{CH}_{4}$ concentration 15-19 times over a four-week dark incubation period and estimated potential peak production rate by calculating the greatest slope of total flask $\mathrm{CH}_{4}$ per unit time generated by at least three points that also produced an $r^{2}>0.9$.

\section{Synthesis of regional waterfowl impoundment area}

We generated an estimate of total area of public waterfowl impoundments that are analogous to our field site, MI10N, in terms of salinity and management goals for vegetation and waterfowl, and also located within the southeastern United States (Alabama, Arkansas, Delaware, Florida, Georgia, Kentucky, Louisiana, Maryland, North Carolina, Tennessee, and Virginia). We reviewed Comprehensive Conservation Plan documents for 107 National Wildlife Refuges and requested data from all 13 state natural resources agencies. We counted freshwater impoundments managed for moist soil or emergent marsh vegetation specifically to provide habitat for wildlife. When possible, we excluded "green tree" reservoirs (forested), seasonally flooded agricultural lands, and managed brackish marshes. No comprehensive data exists for vast areas of privately owned impoundments and state data was not available for northern and southwestern portions of Louisiana, so 
our calculated total may underestimate the true area of managed emergent freshwater waterfowl habitats by as much as $50 \%$.

\section{Waterfowl impoundment methane flux estimate}

Two recent literature syntheses provide potential estimates for waterfowl impoundment $\mathrm{CH}_{4}$ flux (Bridgham et al. 2006, Turetsky et al. 2014). From the synthesis of Bridgham et al. (2006), we culled data from forested wetlands and any wetlands that do not provide suitable waterfowl habitat, included the estimate from our study (including data from bird and no-bird plots separately), and recalculated a mean to represent a rate for waterfowl impoundments. We use Turetsky et al.'s reported daily mean of $\mathrm{CH}_{4}$ flux for graminoid-dominated wetlands, as waterfowl impoundments are typically managed for grasses, sedges, and rushes, and convert it to an annual mean using Bridgham et al.'s conversion factor of 0.36 . Both approaches yielded similar results (43.0 and $41.4 \mathrm{~g}$ $\mathrm{CH}_{4} \cdot \mathrm{m}^{-2} \cdot \mathrm{yr}^{-1}$ ), so we averaged them and multiplied by our conservatively estimated area of freshwater waterfowl impoundments to yield our estimate of total annual $\mathrm{CH}_{4}$ flux from these wetlands.

Because of the spatial and temporal variability of waterfowl flocks and their uncertain distribution across privately owned wetlands and ponds, it is difficult to estimate with certainty the grazing impact of the 10 million overwintering waterfowl in the southeastern United States (U.S. Fish and Wildlife Service 2015a). Nevertheless, if we coarsely assume that half of this population overwinters on the region's 57,000 ha of publicly managed freshwater waterfowl impoundments(Appendix S1: Table S1), then mean density is roughly 90 birds ha $^{-1}$, similar to peak density of 110 recorded at our study impoundment. Thus, as a first approximation, we conclude that waterfowl grazing intensity at our study site is similar to that of other similar habitats in the same region.

\section{Results And Discussion}

Waterfowl grazed heavily at our field site; each 4- $\mathrm{m}^{2}$ plot received a mean of 42 and $28 \mathrm{~h}$ of swan and duck use, respectively, per winter (Appendix S1: Fig. S1). Impacts on aquatic vegetation were significant. We found that exclosures, as intended, prevented consumption of roots and tubers, leading to significantly greater belowground biomass (Fig. 3A) and dramatically denser and more rapidly emerging E. quadrangulata culms (Fig. 3B). Waterfowl exclusion was also associated with significant differences in $\mathrm{O}_{2}$-sensitive $\mathrm{CH}_{4}$ and $\mathrm{N}$ biogeochemical processes. We observed dramatically reduced $\mathrm{CH}_{4}$ emission from exclosures, which emitted a mean of $69 \mathrm{~g}$ $\mathrm{CH}_{4} / \mathrm{m}^{2}$ over the 21-month study, whereas bird-grazed plots emitted a mean of $230 \mathrm{~g} \mathrm{CH}_{4} / \mathrm{m}^{2}$ over the same time period (a 230\% increase associated with herbivore presence; Fig. 4A, B). Extractable nitrate was greater in surface soils of ungrazed exclosures (Fig. 3C), indicating
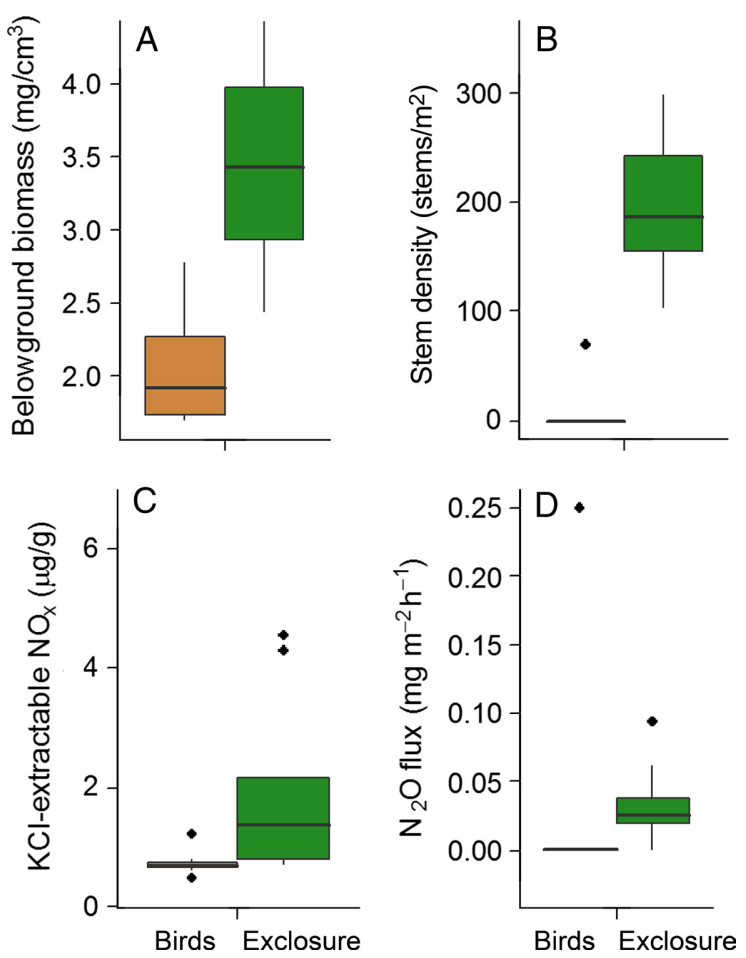

FIG. 3. Waterfowl grazing impacts on vegetation and oxygen-sensitive soil-nitrogen processes. Paired Tukey box plots (whiskers represent 1.5 of interquartile range) of field data collected from bird-impacted (brown) and exclosure (green) plots at Mattamuskeet National Wildlife Refuge in North Carolina, USA. (A) Belowground biomass in top $15 \mathrm{~cm}$ of soil $(P=0.002)$; (B) E. quadrangulata emergent stem density $(P<0.001) ;(C)$ plant-available nitrate/nitrite in the surface soil $(0-5 \mathrm{~cm} ; P=0.03)$; and (D) nitrous oxide flux $(P=0.02)$. $P$ values are generated from Welch's two-sample $t$ tests of data log-transformed to better meet assumptions of normality and variance homogeneity. All data are from May 2014 except belowground biomass (April 2013). (Colour figure can be viewed at wileyonlinelibrary.com.)

an enhancement in aerobic nitrification. Nitrous oxide emission from exclosures was also significantly greater (Fig. 3D), indicating that a lack of herbivore pressure enhanced the capacity of wetland soil to cycle $\mathrm{N}$.

We observed that anaerobically incubated soils from grazed and un-grazed sediments did not exhibit significantly different rates of $\mathrm{CH}_{4}$ production (Appendix S1: Fig. S2), and yet pore-water $\mathrm{CH}_{4}$ reached greater concentrations in grazed plots (Fig. 5), suggesting that differences in observed $\mathrm{CH}_{4}$ flux were driven by $\mathrm{CH}_{4}$ oxidation, rather than production. Our mesocosm investigation into the effects of fecal inputs did not yield any consistent significant differences in $\mathrm{CH}_{4}$ emission (Fig. S3), suggesting that waterfowl feces are not likely to be an important driver of $\mathrm{CH}_{4}$ emission patterns.

We observed significant differences in $\mathrm{CH}_{4}$ dynamics between 2013 and 2014 related to site hydrology governed by prescribed drawdowns and floods (Fig. 4C), which emphasizes the sensitivity of $\mathrm{CH}_{4}$ emission to the availability oxidants. The vast majority of $\mathrm{CH}_{4}(72 \%$ and 


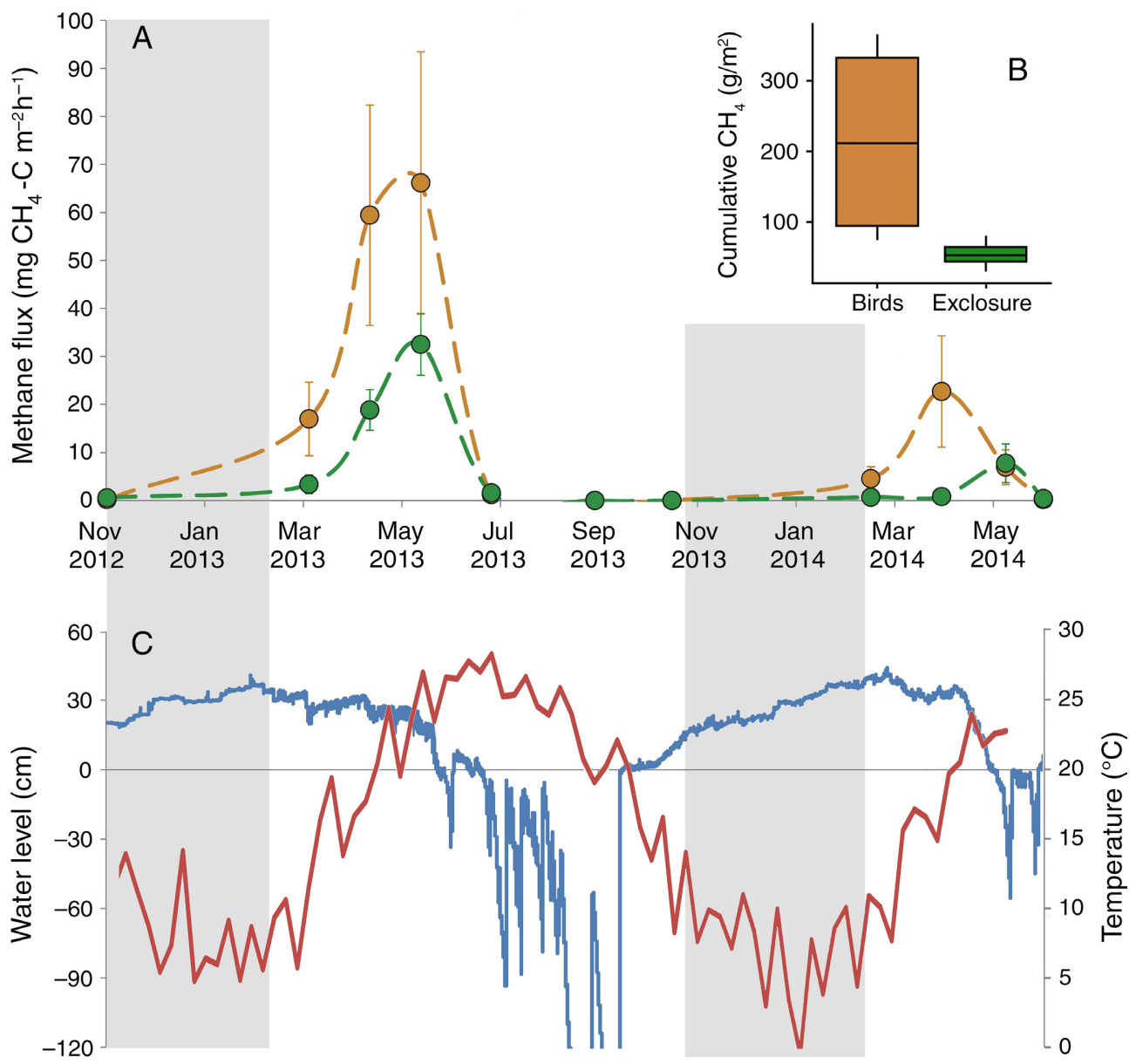

FIG. 4. Effects of waterfowl on seasonal methane flux and long-term cumulative emission in context of site conditions. (A) Seasonal mean $( \pm \mathrm{SE}) \mathrm{CH}_{4}$ flux measured in bird-affected (brown) and exclosure (green) plots at Mattamuskeet National Wildlife Refuge in North Carolina, USA from December 2012 through June 2014. (B) Tukey boxplots (whiskers represent 1.5 of interquartile range) of cumulative $\mathrm{CH}_{4}$ emitted over the course of the study based on extrapolation of flux between sampling periods. We found mean cumulative $\mathrm{CH}_{4}$ flux to be significantly higher from "bird" plots $(P=0.026$; Welch's one-tailed $t$ test $)$. Data were log-transformed to conform to the assumption of variance homogeneity. (C) Water level (blue curve) and water temperature (red curve) are the principle abiotic factors influencing seasonal fluctuations in $\mathrm{CH}_{4}$ flux over the course of the experiment. Gray shading delineates peak waterfowl seasons. Maximum depth of water level recorders in soil is approximately $120 \mathrm{~cm}$.

$93 \%$ in 2014 and 2013, respectively) was emitted during a critical window of ideal conditions in late spring/early summer. With the site in continuous flood starting each fall and with emergent vegetation die-back in winter, the only source of $\mathrm{O}_{2}$ to wetland sediments for months leading up to these high-emissions windows was via the slow process of diffusion. As sediment and surface water temperatures increased, so did respiration and biological $\mathrm{O}_{2}$ demand, while rates of $\mathrm{O}_{2}$ diffusion decreased. These processes worked in concert to severely deplete sediments of $\mathrm{O}_{2}$ and alternative electron acceptors. In such reduced conditions, $\mathrm{CH}_{4}$ production was most efficient and $\mathrm{CH}_{4}$ oxidation was severely limited. As water levels dropped at our field site during early summer, surface soils were eventually exposed and oxidized, which led to an immediate decrease in $\mathrm{CH}_{4}$ emission by two orders of magnitude (Fig. 4A). Following this seasonal crash in $\mathrm{CH}_{4}$ emissions, the differences in nitrate availability and nitrous oxide emission between grazed and ungrazed wetlands disappeared. These patterns of interaction between hydrology and $\mathrm{CH}_{4}$ further indicated that herbivory prevented the development of plant-mediated $\mathrm{O}_{2}$ transport pathways and that this process drove the dramatic biogeochemical differences we observed at our field site.

Our experimental results provide field evidence that intense waterfowl grazing exacerbates $\mathrm{CH}_{4}$ emissions and inhibits $\mathrm{N}$ cycling. Exclosure of waterfowl yielded effects consistent with our hypothesis that waterfowl herbivory would diminish $\mathrm{O}_{2}$ transport into wetland sediments (Fig. 1). While herbivory could also reduce the capacity for plant-mediated $\mathrm{CH}_{4}$ emission and fecal nutrient inputs may not be entirely irrelevant to $\mathrm{CH}_{4}$ dynamics, our data indicate that soil $\mathrm{O}_{2}$ availability was a far more important factor governing $\mathrm{CH}_{4}$ emissions 


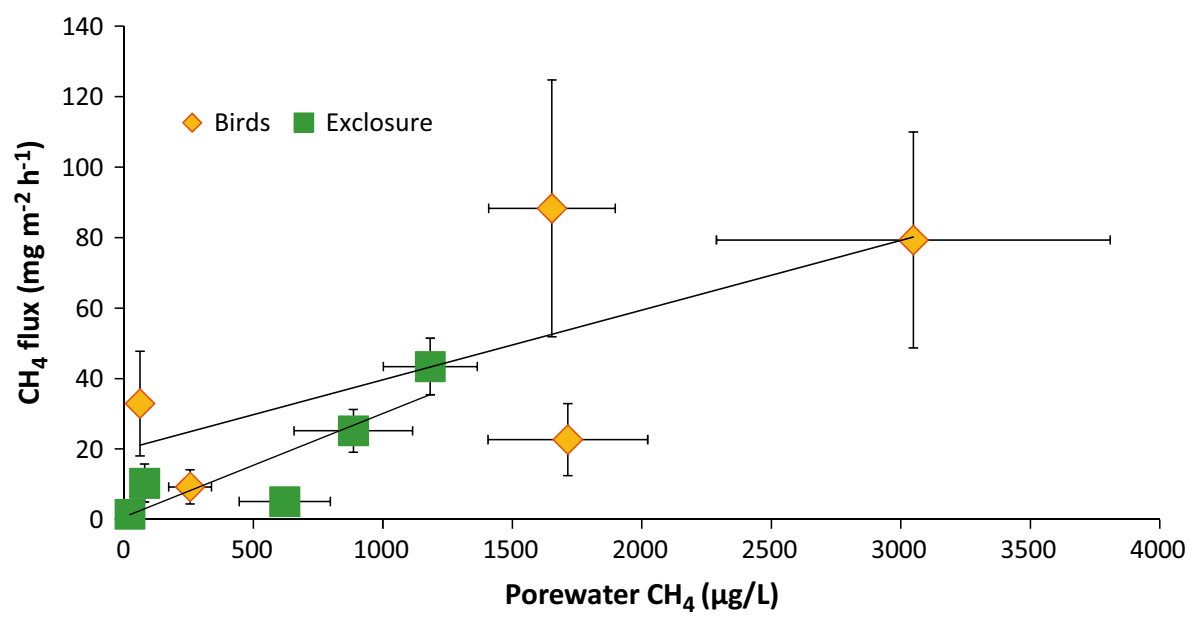

FIG. 5. Relationships between mean porewater methane $\left(\mathrm{CH}_{4}\right)$ concentration and mean $\mathrm{CH}_{4}$ flux measured in experimental plots at Mattamuskeet National Wildlife Refuge in North Carolina, USA during high $\mathrm{CH}_{4}$ flux sampling dates (April, May, and June of 2013; April and May of 2014). Error bars represent standard errors of the mean. (Colour figure can be viewed at wileyonlinelibrary.com.)

(Fig. 4B). Differences we observed in porewater $\mathrm{CH}_{4}$ concentration (Fig. 5), soil nitrate availability (Fig. 3C), and $\mathrm{N}_{2} \mathrm{O}$ emissions (Fig. 3D) are in congruence with our finding that herbivore-alteration of plant rhizosphere oxidation is the key mechanism driving $\mathrm{CH}_{4}$ emission. Together, these results demonstrate that top-down trophic interactions (Silliman et al. 2005) can control wetland biogeochemical cycling in areas that host large populations of aquatic herbivores, which alter plantfacilitated soil-atmosphere gas exchange.

We find that herbivores can prevent the formation of an oxidized rhizosphere and fundamentally change wetland biogeochemical function, an observation that augments the paradigm of emergent vegetation increasing wetland $\mathrm{CH}_{4}$ emissions (Laanbroek 2010, Turetsky et al. 2014). Zones of emergent aquatic vegetation are hotspots for $\mathrm{CH}_{4}$ emission, but herbivore disturbance can exacerbate emissions rather than reduce them, as might be intuited from clipping experiments (Schimel 1995, Shannon et al. 1996, Kelker and Chanton 1997). Clipping temporarily shuts off plant-mediated $\mathrm{CH}_{4}$ transport without significantly changing the availability of alternate electron acceptors in poised soils. In contrast, bird herbivory delays the development of an oxidized rhizosphere, which greatly inhibits the capacity of soils to oxidize $\mathrm{CH}_{4}$.

In light of recent studies on the dramatic alterations to global biogeochemical cycling brought on by the Pleistocene and Anthropocene extinctions and depletions of megafauna (Malhi et al. 2016), the fundamental importance of top-down impacts on biogeochemistry should be expected in any ecosystem where larger fauna persist. Others studies have documented contemporary trophic interactions leading to major changes in regional carbon budgets (Schmitz et al. 2013), but our study provides important context for how changes in wildlife populations, as brought on by management, habitat degradation, or climate warming, may influence $\mathrm{CH}_{4}$ emissions. We speculate that other dominant wetland herbivores, such as nutria along North America's Gulf Coast (Evers et al. 1998) or moose in boreal regions (Pastor et al. 1988), may provide similarly important and unrecognized top-down control on wetland biogeochemical function.

Historic losses of North American waterfowl populations since pre-Columbian times have greatly reduced the pervasiveness of the herbivory effects on wetland biogeochemistry we document in this study. Yet, dramatic population recoveries over recent decades (North American Waterfowl Management Plan Committee 2012; Fig. 6A) combined with losses of roughly half of historic wetland cover, both nationwide (Dahl 2011), and on the North Carolina coastal plain in particular (North Carolina Department of Environment, Health, and Natural Resources 1991, Cashin et al. 1992, Carle 2011, O’Driscoll 2012; Fig. 6B), have concentrated waterfowl in remaining habitats (Fig. 6C). Therefore, the biogeochemical effects of waterfowl herbivory in North America are probably stronger today than at any time in the past century, and they are likely to continue to strengthen as long as wetland degradation and waterfowl population recovery continue.

The premium waterfowl habitats in the southeast, within which birds are most concentrated, are moist-soil impoundments managed specifically for birds (Johnson and Montalbano 1989). While these waterfowl impoundments vary geographically in soil type and plant species, they are uniform with respect to the most important factors affecting $\mathrm{CH}_{4}$ emission: hydrology and emergent vegetation cover. Under conventional moist soil management, impoundments experience long periods of inundation during the winter months (Strader et al. 2005), setting up the potential for extreme $\mathrm{CH}_{4}$ emissions during the early part of the growing season, as we observe in our experiment. A management goal for these habitats: to produce aquatic plants 

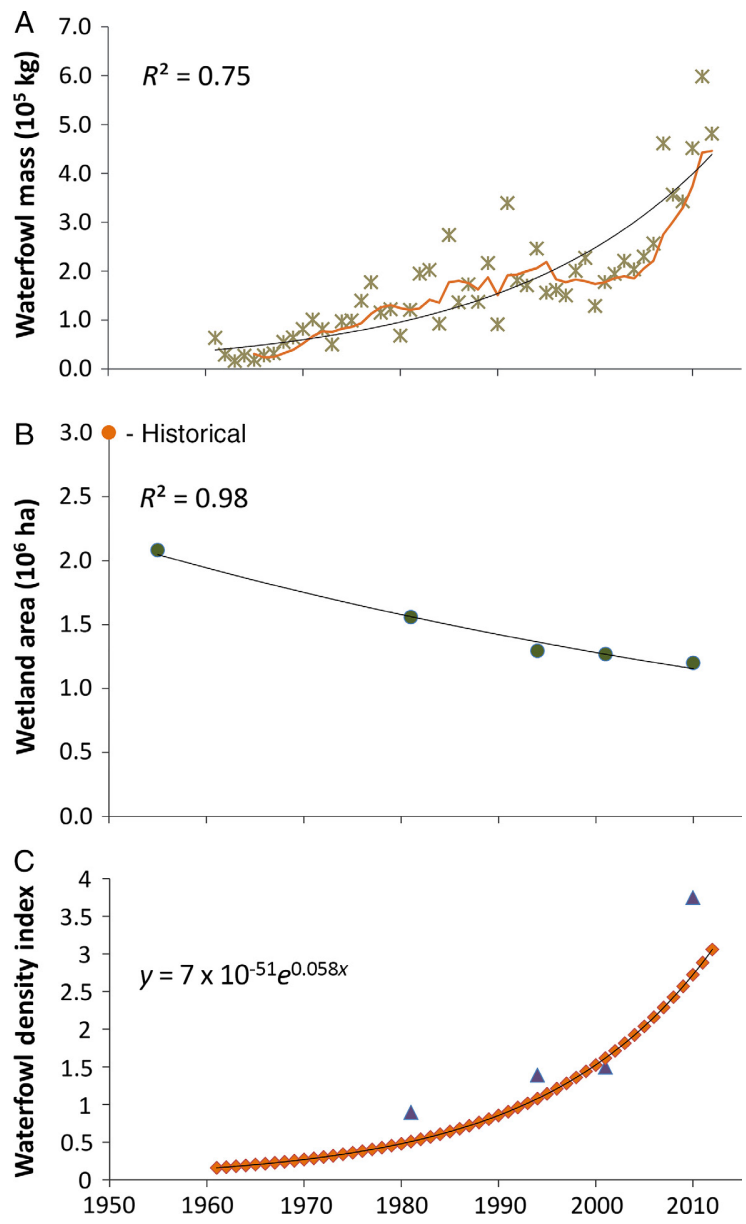

FIG. 6. Wetland loss and recovery of waterfowl populations have led to an increase in waterfowl density over the past $50 \mathrm{yr}$. (A) Mass of overwintering ducks (Drilling et al. 2002), Tundra Swan (Cygnus columbianus; Limpert and Earnst 1994) and Snow Goose (Chen caerulescens; Mowbray et al. 2000 at Mattamuskeet National Wildlife Refuge based on midwinter aerial counts by the U.S. Fish and Wildlife Service from 1961 to 2012 (Wires 2015) with positive exponential and moving 5-yr mean trend lines. (B) Wetland land cover on the North Carolina coastal plain in pre-1900s (North Carolina Department of Environment, Health, and Natural Resources 1991), 1955, 1981 (Cashin et al. 1992), 1994, 2001 (Carle 2011), and 2010 (O’Driscoll 2012) with negative exponential trend line for modern data. (C) Exponentially increasing trend and individual points (triangles) in waterfowl density index are based on ratios of waterfowl mass and wetland area from panels B and A, respectively. (Colour figure can be viewed at wileyonlinelibrary.com.)

preferred by waterfowl, guarantees that herbivory effects will be strong in the presence of dense herbivore populations. Given that the development of aerenchyma for facilitating $\mathrm{O}_{2}$ transport to the rhizosphere through radial $\mathrm{O}_{2}$ loss (Armstrong 1964) is ubiquitous among aquatic plants (Sculthorpe 1967), we should expect that overgrazing has the potential to influence $\mathrm{CH}_{4}$ emissions across a wide geographic range of impoundment habitats.

Based on impoundment area reported by government management agencies and on syntheses of $\mathrm{CH}_{4}$ emissions rates from analogous habitats (Bridgham et al. 2006, Turetsky et al. 2014; Appendix S1: Table S2), we estimate that 57000 ha of public waterfowl impoundments in the southeastern United States (Appendix S1: Table S1) emit $24 \mathrm{Gg} \mathrm{CH}_{4} / \mathrm{yr}$ without invoking any bird effects. Our experimental results of a $230 \%$ increased cumulative $\mathrm{CH}_{4}$ emission suggest that if we were to consider herbivory effects, the $\mathrm{CH}_{4}$ emission from southeastern impoundments could be more than tripled to $80 \mathrm{Gg} \mathrm{CH}_{4} / \mathrm{yr}$, equivalent to $6.5 \%$ of the $1238 \mathrm{Gg} \mathrm{CH}_{4} / \mathrm{yr}$ emitted by landfills in this region (Environmental Protection Agency 2015).

State and federal wildlife managers have an opportunity to reduce $\mathrm{CH}_{4}$ emissions through alteration of moist-soil impoundment management prescriptions and potentially offset portions of refuge or agency $\mathrm{C}$ footprints. Yet, our analysis shows that even if such practices were adopted en masse across all the publicly owned freshwater emergent waterfowl impoundments in the southeast, the impact on regional $\mathrm{CH}_{4}$ emissions would be relatively small; the widely recognized $\mathrm{CH}_{4}$ emitters (fossil fuel industry, cattle, landfills, rice paddies) still dominate global and national budgets (Myhre et al. 2013). Nevertheless, as governments and NGOs continue to investigate opportunities for greenhouse gas mitigation through land management (Fish and Wildlife Service 2010), recognition of the importance of trophic interaction controls on wetland $\mathrm{CH}_{4}$ will be critically important.

The implications of our finding that waterfowl herbivory can disrupt wetland $\mathrm{N}$ cycling may be of even greater importance for wildlife management, given that habitat degradation caused by eutrophication has a more immediate and localized effect on wildlife than does global warming. We found that the long-term $\mathrm{N}$ removal process of denitrification was limited at our field site proximally by low nitrate, and ultimately by herbivory and the lack of plant-mediated $\mathrm{O}_{2}$ transport. Based on depth of water drawdown and surface water $\mathrm{N}$ concentrations we estimate that the impoundment exported 14 and $22 \mathrm{~kg} \mathrm{~N} / \mathrm{ha}$ to Lake Mattamuskeet in 2013 and 2014, respectively (Table 1, Winton et al. 2016), a range similar to $\mathrm{N}$ loading estimates for fertilized agricultural lands in

TABLE 1. Hydrologic drawdown and total $\mathrm{N}$ export across two years from impoundment MI10N at Mattamuskeet National Wildlife Refuge in North Carolina, USA.

\begin{tabular}{lcccccccc}
\hline \hline Year & $\begin{array}{c}\text { Size } \\
(\mathrm{ha})\end{array}$ & $\begin{array}{c}\text { Drawdown } \\
(\mathrm{cm})\end{array}$ & $\begin{array}{c}\text { Drawdown } \\
\left(\mathrm{m}^{3}\right)\end{array}$ & $\begin{array}{c}\text { Surface water } \\
\mathrm{N}(\mathrm{mg} / \mathrm{L})\end{array}$ & $\begin{array}{c}\text { N export } \\
(\mathrm{kg})\end{array}$ & $\begin{array}{c}\text { N export } \\
(\mathrm{kg} / \mathrm{ha})\end{array}$ & $\begin{array}{c}\text { Peak no. } \\
\text { swans }\end{array}$ & $\begin{array}{c}\text { Peak no. } \\
\text { ducks }\end{array}$ \\
\hline 2014 & 88 & 34 & 299,200 & 6.49 & 1,941 & 22 & 6,450 & 25,529 \\
2013 & 88 & 16 & 140,800 & 8.79 & 1,238 & 14 & 5,036 & 5,484 \\
\hline
\end{tabular}


the North Carolina coastal plain (Deal et al. 1986). Given that eutrophication of ecosystems is a growing concern globally (Smith 2003), as well as locally at Lake Mattamuskeet (North Carolina Department of Health Environment and Natural Resources 2013, U.S. Fish and Wildlife Service 2015b), it will be necessary for managers to understand the impact of herbivory and waterfowl impoundment habitats on nutrient loading in order to optimize landscape-scale habitat quality.

Since this study demonstrates some negative environmental consequences of high densities of herbivorous birds, we feel it necessary to mention that North American waterfowl populations provide many important ecological functions and cultural values. Rather than advocate for a reduction in bird populations (which would be undoing nearly a century of conservation effort), we point out that the undesirable herbivory effects could likely be mitigated by simple changes to hydrologic management prescriptions of waterfowl impoundments. Earlier seasonal drainage and oxidation of the surface soils of our study impoundment in 2014, led to a roughly $80 \%$ reduction in $\mathrm{CH}_{4}$ emissions compared to 2013. Earlier seasonal drainage could not only reduce $\mathrm{CH}_{4}$, but also enhance coupled nitrification-denitrification, thus reducing the potency of impoundment habitats as exporters of $\mathrm{N}$. Of course such changes in hydrologic management may impose biogeochemical (such as $\mathrm{N}_{2} \mathrm{O}$ and $\mathrm{CO}_{2}$ emissions) and/or habitat quality trade-offs. We recommend further research in managed waterfowl wetlands that investigate whether altered seasonal hydrologic regimes may improve greenhouse gas and biogeochemical performance while simultaneously meeting habitat and wildlife goals.

\section{ACKNOWLEDGMENTS}

We thank J. Bills for helping instrument the field site; W. Willis for assisting with laboratory analyses; M. River, M. Ho, and R. Lauzon for providing help and companionship in the field; P. Campbell, A. Stewart, J. Fringeli, and M. Moorman of the U.S. Fish and Wildlife Service for generous hospitality and providing access to the field site; J. Parker for helping design and construct static chambers; D. Prasodjo for providing visual basic programming expertise; M. Barnes for maintaining and providing space for mesocosms in the Duke Greenhouse. The manuscript was improved by comments from P. Megonigal, W. Hartman, E. Bernhardt, D. Richter, and B. Silliman. Funding was provided by the Carolina Bird Club, the Duke University Wetland Center Endowment, and the Duke University Graduate School.

\section{Literature Cited}

Anderson, M., and J. Low. 1976. Use of sago pondweed by waterfowl on the Delta Marsh, Manitoba. Journal of Wildlife Management 40:233-242.

Armstrong, W. 1964. Oxygen diffusion from the roots of some British bog plants. Nature 204:801-802.

Augustine, D., and S. McNaughton. 1998. Ungulate effects on the functional species composition of plant communities: herbivore selectivity and plant tolerance. Journal of Wildlife Management 62:1165-1183.
Badzinski, S. S., C. D. Ankney, and S. A. Petrie. 2006. Influence of migrant tundra swans (Cygnus columbianus) and Canada geese (Branta canadensis) on aquatic vegetation at Long Point, Lake Erie, Ontario. Hydrobiologia 567:195-211.

Baldassarre, G. A., E. G. Bolen, and A. Saunders. 2006. Waterfowl ecology and management. Krieger, Malabar, Florida, USA.

Bodelier, P., A. Hahn, I. Arth, and P. Frenzel. 2000. Effects of ammonium-based fertilisation on microbialprocesses involved in methane emission from soils planted with rice. Biogeochemistry 51:225-257.

Bodelier, P. L. E., M. Stomp, L. Santamaria, M. Klaassen, and H. J. Laanbroek. 2006. Animal-plant-microbe interactions: direct and indirect effects of swan foraging behaviour modulate methane cycling in temperate shallow wetlands. Oecologia 149:233-244.

Boon, P. I., andB. K. Sorrell. 1995. Methane fluxes from an Australian floodplain wetland: the importance of emergent macrophytes .Journal of the North American Benthological Society 14:582-598.

Bridgham, S. D., J. Patrick Megonigal, J. K. Keller, N. B. Bliss, and C. Trettin. 2006. The carbon balance of North American wetlands. Wetlands 26:889.

Carle, M. V. 2011. Estimating wetland losses and gains in coastal North Carolina: 1994-2001. Wetlands 31:1275-1285.

Cashin, G., J. Dorney, and C. Richardson. 1992. Wetland alteration trends on the North Carolina coastal plain. Wetlands 12:63-71.

Dacey, J., and M. Klug. 1979. Methane efflux from lake sediments through water lilies. Science 203:1253-1255.

Dahl, T. E. 2011. Status and trends of wetlands in the conterminous United States 2004 to 2009. Fish and Wildlife Service, Washington, D.C., USA

Deal, S. C., J. W. Gilliam, R. W. Skaggs, and K. D. Konyha. 1986. Prediction of nitrogen and phosphorus losses as related to agricultural drainage system design. Agriculture, Ecosystems and Environment 18:37-51.

Ding, W., Z. Cai, and H. Tsuruta. 2005. Plant species effects on methane emissions from freshwater marshes. Atmospheric Environment 39:3199-3207.

Dingemans, B. J. J., E. S. Bakker, and P. L. E. Bodelier. 2011. Aquatic herbivores facilitate the emission of methane from wetlands. Ecology 92:1166-1173.

Doughty, C. E., J. Roman, S. Faurby, A. Wolf, A. Haque, E. S. Bakker, Y. Malhi, J. B. Dunning, and J.-C. Svenning. 2015. Global nutrient transport in a world of giants. Proceedings of the National Academy of Sciences USA 133:868-873.

Drilling, N., R. Titman, and F. McKinney. 2002. Mallard (Anas platyrhynchos) In A. Poole, editor. The birds of North America online. Cornell Laboratory of Ornithology, Ithaca, New York, USA. https://birdsna.org/Species-Account/bna/ species/mallar/introduction

Environmental Protection Agency. 2015. Inventory of US Greenhouse Gas Emissions and Sinks: 1990-2013. EPA, Washington, D.C., USA

Evers, D. E., C. Sasser, and J. Gosselink. 1998. The impact of vertebrate herbivores on wetland vegetation in Atchafalaya Bay, Louisiana. Estuaries 21:1-13.

Firestone, M. K. 1982. Biological denitrification. Pages 289-326 in F. J. Stevenson, editor. Nitrogen in agricultural soils. American Society of Agronomy, Madison, Wisconsin, USA.

Fish and Wildlife Service. 2010. Rising to the urgent challenge: strategic plan for responding to accelerating climate change. U.S. Fish and Wildlife Service, Washington, D.C., USA.

Froelich, A. J., and D. M. Lodge. 2000. Waterfowl-induced changes in submerged and emergent macrophyte communities at Lake Mattamuskeet, NC, USA. Pages 43-60 in 
F. A. Comin, J. A. Herrera-Silveira, and J. Ramirez-Ramirez, editors. Limnology and aquatic birds: monitoring, modelling and management. Universidad Autonoma de Yucatan, Merida, Yucatan, Mexico.

Green, M., and J. Etherington. 1977. Oxidation of ferrous iron by rice (Oryza sativa L.) roots: a mechanism for waterlogging tolerance? Journal of Experimental Botany 28:678-690.

Hahn, S., S. Bauer, and M. Klaassen. 2007. Quantification of allochthonous nutrient input into freshwater bodies by herbivorous waterbirds. Freshwater Biology 53:181-193.

Huang, Y., H. Wang, H. Huang, Z. W. Feng, Z. H. Yang, and Y. C. Luo. 2005. Characteristics of methane emission from wetland rice-duck complex ecosystem. Agriculture, Ecosystems and Environment 105:181-193.

Hulme, P. 1996. Herbivory, plant regeneration, and species coexistence. Journal of Ecology 84:609-615.

Idestam-Almquist, J. 1998. Waterfowl herbivory on Potamogeton pectinatus in the Baltic Sea. Oikos 81:323-328.

Jespersen, D. N., B. K. Sorrell, and H. Brix. 1998. Growth and root oxygen release by Typha latifolia and its effects on sediment methanogenesis. Aquatic Botany 61:165-180.

Johnson, F. A., and F. Montalbano III. 1989. Southern reservoirs and lakes. Pages 93-116 in L. M. Smith, R. L. Pederson, and R. M. Kaminski, editors. Habitat management for migrating and wintering waterfowl in North America. Texas Tech University Press, Lubbock, Texas, USA.

Kampbell, D. H., J. T. Wilson, and S. A. Vandegrift. 1989. Dissolved oxygen and methane in water by a GC headspace equilibration technique. International Journal of Environmental Analytical Chemistry 36:249-257.

Kelker, D., and J. Chanton. 1997. The effect of clipping on methane emissions from Carex. Biological Research 39: $37-44$.

King, G. M. 1994. Associations of methanotrophs with the roots and rhizomes of aquatic vegetation. Applied and Environmental Microbiology 60:3220-3227.

Laanbroek, H. J. 2010. Methane emission from natural wetlands: interplay between emergent macrophytes and soil microbial processes. A mini-review. Annals of Botany 105: 141-153.

Limpert, R. J., and S. L. Earnst. 1994. Tundra Swan (Cygnus columbianus). InA. Poole, editor. The birds of North America online. Cornell Laboratory of Ornithology, Ithaca, New York, USA. https://birdsna.org/Species-Account/bna/species/ tunswa/introduction

Malhi, Y., C. E. Doughty, M. Galetti, F. A. Smith, J.-C. Svenning, and J. W. Terborgh. 2016. Megafauna and ecosystem function from the Pleistocene to the Anthropocene. Proceedings of the National Academy of Sciences USA 113:838-846.

Michaud, S. C., and C. J. Richardson. 1989. Relative radial oxygen loss in five wetland plants. Pages 501-507 in Constructed wetlands for wastewater treatment: municipal, industrial and agricultural. Lewis Publishers, Chelsea, Massachusetts, USA.

Milchunas, D., O. Sala, and W. Lauenroth. 1988. A generalized model of the effects of grazing by large herbivores on grassland community structure. American Naturalist 132:87-106.

Mowbray, T. B., F. Cooke, and B. Ganter. 2000. Snow Goose (Chen caerulescens). http://bna.birds.cornell.edu/bna/species/ 514

Myhre, G., et al. 2013. Anthropogenic and natural radiative forcing. Pages 1-124 in T. F. Stocker, D. Qin, G.-K. Plattner, M. Tignor, S. K. Allen, J. Boschung, A. Nauels, X. Y. V. Bex, and P. M. Midgley, editors. Climate change 2013: the physical science basis. Cambridge University Press, Cambridge, UK

North American Waterfowl Management Plan Committee. 2012. North American Waterfowl Management Plan 2012 people conserving waterfowl and wetlands. U.S. Fish and Wildlife Service, Washington, D.C., USA.

North Carolina Department of Environment, Health, and Natural Resources. 1991. Original extent, status and trends of wetlands in North Carolina: a report to the N.C. legislative study commission on wetlands protection. North Carolina Department of Environment, Health, and Natural Resources, Raleigh, North Carolina, USA.

North Carolina Department of Health Environment and Natural Resources. 2013. Lake \& Reservoir Assessments Tar-Pamlico River Basin. North Carolina Department of Environment, Health, and Natural Resources, Raleigh, North Carolina, USA.

O'Driscoll, M. A. 2012. The 1909 North Carolina drainage act and agricultural drainage effects in Eastern North Carolina. Journal of North Carolina Academy of Science 128:59-73.

Olff, H., and M. Ritchie. 1998. Effects of herbivores on grassland plant diversity. Trends in Ecology and Evolution 13: 261-265.

Pastor, J., R. Naiman, B. Dewey, and P. McInnes. 1988. Moose, microbes, and the boreal forest. BioScience 38:770-777.

Peel, M. C., B. L. Finlayson, and T. A. Mcmahon. 2007. Updated world map of the Köppen-Geiger climate classification. Hydrology and Earth System Sciences 11: 1633-1644.

Petruzzella, A., R. D. Guariento, A. D. R. Gripp, C. C. Marinho, M. P. Figueiredo-Barros, and F. D. A. Esteves. 2015. Herbivore damage increases methane emission from emergent aquatic macrophytes. Aquatic Botany 127:6-11.

Post, D. M., J. P. Taylor, J. F. Kitchell, M. H. Olson, D. E. Schindler, and B. R. Herwig. 1998. The role of migratory waterfowl as nutrient vectors in a managed wetland. Conservation Biology 12:910-920.

Reddy, K., W. Patrick, and C. Lindau. 1989. Nitrificationdenitrification at the plant root-sediment interface in wetlands. Limnology and Oceanography 34:1004-1013.

Rodewald, P., editor. 2015. The birds of North America online. Cornell Laboratory of Ornithology, Ithaca, New York, USA.

Schimel, J. P. 1995. Plant transport and methane production as controls on methane flux from arctic wet meadow tundra. Biogeochemistry 28:183-200.

Schmitz, O. J., et al. 2013. Animating the carbon cycle. Ecosystems 17:344-359.

Sculthorpe, C. D. 1967. The biology of aquatic vascular plants. St. Martin's Press, New York.

Shannon, R., J. White, J. Lawson, and B. Gilmour. 1996. Methane efflux from emergent vegetation in peatlands. Journal of Ecology 84:239-246.

Silliman, B., J. Van De Koppel, M. D. Bertness, L. E. Stanton, and I. A. Mendelssohn. 2005. Drought, snails, and large-scale die-off of southern US salt marshes. Science 310:1803-1806.

Smith, V. H. 2003. Eutrophication of freshwater and coastal marine ecosystems a global problem. Environmental Science and Pollution Research 10:126-139.

Soil Survey Staff. 2015. Web Soil Survey. http://websoilsurvey. nrcs.usda.gov/

Strack, M., and J. M. Waddington. 2008. Spatiotemporal variability in peatland subsurface methane dynamics. Journal of Geophysical Research 113:1-12.

Strader, R., P. Stinson and M. Jackson. 2005. Moist-soil management guidelines for the US Fish and Wildlife Service Southeast Region. Migratory Bird Field Office, U.S. Fish and Wildlife Service, Jackson, Mississippi, USA.

Sundby, B., C. Vale, I. CaCador, F. Catarino, M. Madureura, and I. Caetano. 1998. Metal-rich concretions on the roots of salt marsh plants: mechanism and rate of formation. Limnology and Oceanography 43:245-252. 
Turetsky, M. R., et al. 2014. A synthesis of methane emissions from 71 northern, temperate, and subtropical wetlands. Global Change Biology 20:2183-2197.

U.S. Fish and Wildlife Service. 2015a. Mid-winter Waterfowl Survey.U.S. Fish and Wildlife Service, Washington, D.C., USA.

U.S. Fish and Wildlife Service. 2015b. Science to support hydrology and water quality management decision-making at Lake Mattamuskeet.U.S. Fish and Wildlife Service, Washington, D.C., USA.

Van Der Nat, F., and J. Middelburg. 1998. Effects of two common macrophytes on methane dynamics in freshwater sediments. Biogeochemistry 43:79-104.

Veen, G. F. C., J. M. Sarneel, L. Ravensbergen, N. Huig, J. van Paassen, W. Rip, and E. S. Bakker. 2013. Aquatic grazers reduce the establishment and growth of riparian plants along an environmental gradient. Freshwater Biology 58:1794-1803.

Wetzel, R. G., and G. E. Likens. 2000. Limnological analyses. Third edition. Springer, New York, New York, USA.
Whalen, S. C. 2005. Biogeochemistry of methane exchange between natural wetlands and the atmosphere. Environmental Engineering Science 22:73-93.

Whiting, G., and J. Chanton. 1993. Primary production control of methane emission from wetlands. Nature 364:794-795.

Wickland, K., R. Striegl, S. Schmidt, and M. Mast. 1999. Methane flux in subalpine wetland and unsaturated soils in the southern Rocky Mountains. Global Biogeochemical Cycles 13:101-113.

Winton, R. S., and C. J. Richardson. 2015. A cost-effective method for reducing soil disturbance-induced errors in static chamber measurement of wetland methane emissions. Wetlands Ecology and Management 24:419-425.

Winton, R. S., M. Moorman, and C. J. Richardson. 2016. Waterfowl impoundments as sources of nitrogen pollution. Water, Air \& Soil Pollution.

Wires, L. 2015. Integrated waterbird management and monitoring. U.S. Fish and Wildlife Service, Bloomington, Minnesota, USA. 